\title{
PERBANDINGAN KEMAMPUAN ARGUMENTASI MAHASISWA PENDIDIKAN BIOLOGI
}

\author{
Fajar Nur'aini ${ }^{1}$, Ihrom Rosyadi ${ }^{2}$, Maretania Arafah ${ }^{3}$, Mega Safrina $^{4}$, \\ Nuri Isnaini ${ }^{5}$, Rahmat Evendi ${ }^{6}$, Bowo Sugiharto ${ }^{7^{*}}$ \\ 1, 2, 3, 4, 5, 6, 7 Pendidikan Biologi, FKIP, Universitas Sebelas Maret Surakarta, Indonesia \\ *Email: bowo@fkip.uns.ac.id
}

Received: Oktober $3^{\text {th }}, 2019$. Accepted: November $2^{\text {nd }}, 2019$. Published: December $2^{\text {th }}, 2019$

\begin{abstract}
The purpose of the studies is to compare the student's argumentation skill at $1^{\text {st }}, 3^{\text {rd }}, 5^{\text {th }}$, and $7^{\text {th }}$ term of Biology Education Faculty of Teacher and TrainingSebelas Maret Universitybased on social science issues. The studies use expos facto method with random sampling technique. The samples are 30 students from each term. The instrument on this research based on TAP (Toulmins Argumentation Pattern) theory. The analytical techniques used are independence $T$ test. The results showed thatstudent on $1^{\text {st }}, 3^{\text {rd }}, 5^{\text {th }}$, and $7^{\text {th }}$ term each have mean score $25,67 \%, 32,11 \%, 37,7 \%, 49,06 \%$. It can be concluded that there are differences of the level of argumentation skill at different term.
\end{abstract}

Keywords: Biology; Argumentation Skill; College Student.

\begin{abstract}
Abstrak
Tujuan dari penelitian ini adalah untuk mengetahui adanya pengaruh jenjang semester terhadap kemampuan berargumentasi Mahasiswa Pendidikan Biologi Fakultas Keguruan dan Ilmu Pendidikan Universitas Sebelas Maret. Metode Penelitian yang digunakan merupakan penelitian expost facto. Teknik sampling yang digunakan adalah teknik random sampling.Sampel yang digunakan yaitu 30 mahasiswa semester 1, 3, 5, dan 7 pada tahun ajaran 2019/2020. Instrumen yang digunakan adalah soal isian yang dikembangkan berdasarkan TAP (Toulmin's Argumentation Pattern). Teknik analisis yang digunakan adalah analisis independence $t$ test. Hasil yang diperoleh yaitu mahasiswa semester 1 , 3, 5, dan 7 berturut-turut mendapatkan rata-rata $25,67 \%, 32,11 \%, 37,7 \%, 49,06 \%$, sehingga mahasiswa dengan jenjang semester lebhi tinggi memiliki keterampilan berargumentasi yang lebih unggul. Dapat disimpulkan bahwa jenjang semestermempengaruhi tingkat kemampuan argumentasi.
\end{abstract}

Kata Kunci : Biologi; Keterampilan Argumentasi; Mahasiswa.

\section{PENDAHULUAN}

Abad ke-21 pendidikan di Indonesia menitikberatkan siswa untuk senantiasa aktif dalam melakukan kegiatan perdebatan mengenai berbagai topik yang berkembang di masyarakat sesuai dengan tingkat ilmu yang dimiliki tiap siswa untuk membangun pengalaman dan pengetahuan (Karyanti dan Komarudin 2017). Berdasarkan penelitian (Amalia, Widodo, dan Rochintaniawati 2018) membangun kemampuan argumentasi yang baik pada berbagai jenjang usia masih mengalami kesulitan. Kemampuan yang lebih untuk dapat mengembangkan kemampuan berpikir yang serius dan terarah, sehingga proses penyelesaian maksimal dan mendapatkan hasil yang tepat (Hasanah dkk., t.t.). 
Menurut Toulmin Argumentasi membentuk proses yang menghasilkan teori atau pernyataan yang memberikan dukungan dan pembenaran dengan didukung oleh data (Mouraz dkk. 2014). Kemampuan argumentasi dinilai berdasar teori, fakta, dan contoh yang dipaparkan. Hal tersebut juga dikatakn Parelman bahwa argumentasi didasarkan atas data nyata, fakta yang mendukung untuk menginterpretasikan secara deskriptif (Hasnunidah dan Susilo 2014).

Argumentasi ilmiah memiliki ciri khusus diantaranya terdapat beberapa komponen berupa claim, evidence, dan justification dibandingkan dengan argumentasi dalam isu-isu tertentu (Ekanara, Rustaman, dan Hernawati 2016). Argumentasi untuk memverifikasi atau menyangkal suatu pernyataan secara ilmiah(Komarudin 2016; Kertayasa 2011; Habibah 2019). Ketika bejalar sains, kemampuan berargumentasi memiliki tujuan utama dalam pembelajaran yang memuat pejelasan mengenai fenomena alam kemudian cara dalam memecahkan masalah serta memahami masalah yang didapatkan (Puspitaningrum, Astutik, dan Supeno 2018; Admoko dan Supriyono 2016). Oleh karna itu, Argumentasi ilmiah yang memiliki kualitas baik harus memenuhi beberapa kriteria. Kriteria tersebut yaitu analitis, teoritis dan empiris (Probosari, Ramli, dan Indrowati 2016)

Kemampuan berargumentasi memungkinkan seseorang untuk mengerti perspektif lain, mengevaluasi kecukupan atau kebutuhan warrant yang ada serta menilai validitas dari pernyataan bersama (Yusri 2016). Ketika siswa menilai validitas argumen ilmiah maka siswa mampu menjadi lebih baik dalam membenarkan masalah mengenai isu-isu tersebut (LIN dan MINTZES 2010). Namun, Ketika siswa diminta untuk berargumentasi, untuk menggabungkan pengetahuan dan pengalaman untuk menguraikan pemahaman sains siswa di tingkat pemikiran abstrak yang lebih tinggi (Kurniawan 2013; Hasanah, Asih, dan Kharisudin 2019). Keterampilan berargumentasi pada mahasiswa yang rendah dapat berpengaruh terhadap hasil belajar (Syafitri, Asyhar, dan Asrial 2016; Saregar 2016) dan menyebabkan mahasiswa tidak mampu bersaing di era yang semakin maju serta kehilangan peluang kerja yang baik (Sanisah 2010; Nagel 2013). Apabila mahasiswa tidak mampu menyelesaikan masalah yang dihadapi maka mahasiswa akan kesulitan menghadapi tantangan di kehidupan yang semakin kompleks (Setyawan 2011; Tahaha dan Rustan 2017). 
Kemampuan berpikir secara konkret yang berhubungan dengan suatu masalah pada jenjang yang lebih tinggi berkembang lebih matang dibandingkan jenjang dibawahnya (Lestari dan Prima 2018; Marliani 2015). Perkembangan kemampuan tersebut dipengaruhi oleh faktor usia dan proses perkembangan berpikir mahasiswa (Ibda 2015). Berdasarkan hal tersebut belum adanya peneliti yang membandingkan kemampuan argumentasi mahasiswa (Herlanti 2014; Setiawati dan Nurlaelah 2017; Handayani 2015). Penelitian ini bertujuan untuk mmembandingkan kemampuan berargumentasi mahasiswa pendidikan biologi FKIP UNS pada jenjang semester 3 dan 7 mengenai isu sosial sains.

\section{METODE}

Penulis memaparkan metode penelitian yang digunakan, termasuk didalamnya adalah teknik pengumpulan dan analisis data. Penelitian dilakukan pada bulan Desember 2019 dan bertempat di Fakultas Keguruan dan Ilmu Pendidikan (FKIP) Universitas Sebelas Maret Surakarta. Metode penelitian yang digunakan dalam penelitian ini adalah penelitian expos facto dengan teknik random sampling. Instrumen yang digunakan berupa soal isian hasil pengembangan oleh (Suraya 2018) melalui media kuisioner online berupa google form. Partisipan yang terlibat dalam penelitian ini adalah mahasiswa Pendidikan Biologi Fakultas Keguruan dan Ilmu Pendidikan UNS semester 1, 3, 5, dan 7. Seluruh data akan dianalisis dengan menggunakan aplikasi SPSS untuk diuji homogenitasnya.

\section{HASIL DAN PEMBAHASAN}

Berdasarkan hasil penilaian tes kemampuan argumentatif yang berpedoman pada Toulmin's Argumen Pattern (TAP) yang dikembangkan oleh (Faiqoh dkk. 2018), data yang diperoleh dapat disajikan sebagai berikut :

Tabel 1. Presentase Kategori Kemampuan Argumentasi Mahasiswa Semester $1,3,5$ dan 7

\begin{tabular}{ccccc}
\hline Kategori & Semester 1 & Semester 3 & Semester 5 & Semester 7 \\
\hline Sangat Rendah & $17 \%$ & $3 \%$ & $11 \%$ & $16 \%$ \\
Rendah & $40 \%$ & $33 \%$ & $20 \%$ & $53 \%$ \\
Cukup & $37 \%$ & $33 \%$ & $41 \%$ & $23 \%$ \\
Tinggi & $3 \%$ & $23 \%$ & $25 \%$ & $3 \%$ \\
Sangat Tinggi & $3 \%$ & $7 \%$ & $3 \%$ & $3 \%$ \\
\hline Rata-rata & $25,67 \%$ & $32,11 \%$ & $37,7 \%$ & $49,06 \%$ \\
\hline
\end{tabular}


Tabel 1 menunjukan bahwa rata-rata nilai tertinggi ke yang rendah dimulai dari mahasiswa semester 7 , semester 5 , semester 3 dan yang paling rendah yaitu mahasiswa semester 1. Nilai ini diambil dari perhitungan kuantitatif dengan menghitung adaya unsur pada setiap jawaban responden. Dengan memperhatikan jawaban dari responden kemudian dianalisis berdasarkan ada tidaknya unsur argumentasi pada setiap jawaban. Hasil menunjukan mahasiswa semester 1 mendapatkan nilai rata-rata $25,67 \%$, mahasiswa semester 3 mendapatkan rata-rata 32,11\%, mahasiswa semester 5 mendapatkan 37,7\%, dan mahasiswa semester 7 mendapatkan rata-rata 49,06\%, yang artinya mahasiswa semester 7 memiliki kemampuan yang lebih unggul dalam kemampuan berargumentasi.

Perkembangan proses berpikir yang terjadi pada manusia berhubungan dengan faktor usia (Ibda 2015). Seiring dengan bertambahnya usia seseorang, maka kemampuan berargumentasinya akan semakin meningkat. Mahasiswa semester 7 cenderung memiliki nilai rata-rata argumentasi lebih tinggi dari mahasiswa semester 1,3,dan 5. Hal ini sesuai sejalan dengan Miles yang menyebutkan bahwa perbedaan jenjang kelas akan berpengaruh signifikan terhadap semua unsur argumentasi (Baan 2016).

Penilaian kemampuan argumentasi berpedoman pada Toulmin's Argumen Pattern (TAP) sebagai landasan teori yang digunakan. Toulmin menyebutkan bahwa argumentasi terdiri dari 5 komponen, yaitu data (data), klaim (claim), pembenaran (warrant), dukungan (backing), dan sanggahan (rebuttal)(Ginanjar dan Utari 2015; Sandhy, Tandililing, dan Oktavianty, t.t.; Zahratul Hikmah dan Suprapto 2019). Seluruh hasil jawaban responden juga dianalisis berdasarkan ada atau tidaknya 4 komponen argumentasi menurut Toulmin, yaitu data (data), klaim (claim), pembenaran (warrant), dukungan (backing). Hasil dari penjumlahan ada atau tidaknya komponen tersebut dapat digambarkan dengan Gambar 1 berikut. 


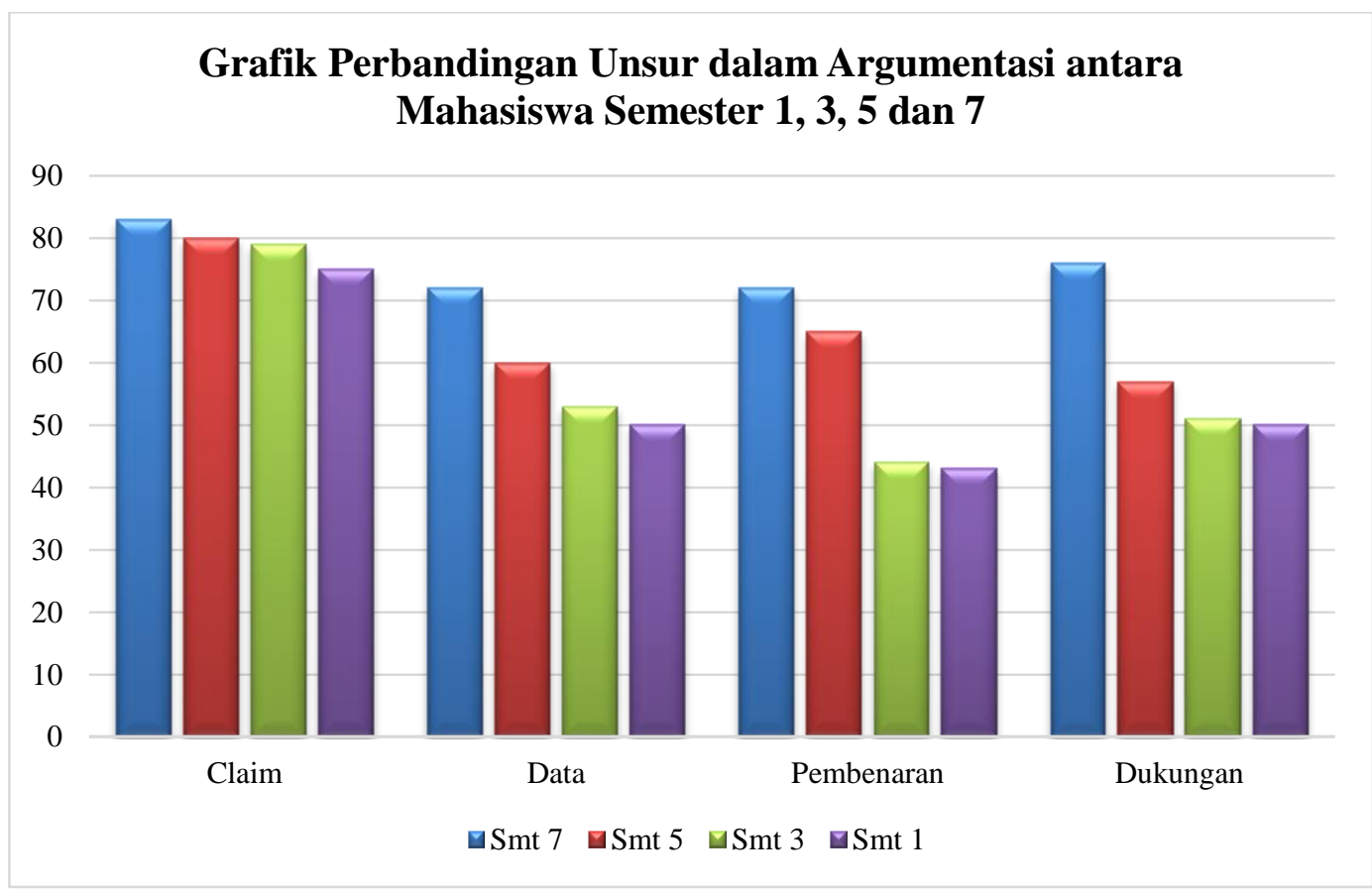

Gambar 1. Grafik Perbandingan Unsur dalam Argumentasi antara Mahasiswa Semester 1, 3, 5 dan 7

Berdasarkan Gambar 1 dapat dilihat bahwa secara keseluruhan mahasiswa dengan jenjang semester lebih tinggi memiliki kemampuan berargumentasi yang lebih unggul dari mahasiswa pada jenjang semester di bawahya. Kemmapuan ini mencakup semua unsur argumentasi baik claim, data, pembenaran, dan dukungan.

Jumlah unsur data (data) cukup jauh perbedaan antara mahasiswa semester 7 menempati posisi tertinggi yaitu 72 dan diantara semester 1, 3, dan 5 hanya memiliki perbedaan yang sedikit dengan selisih 3-5 poin. Mahasiswa semester 7 cenderung menyertakan fakta-fakta yang dapat mendukung claim. Sedangkan mahasiswa semester 1 dan 3 belum lengkap dalam menyertakan data, dan pada mahasiswa semester 5 hanya beberapa yang menyertakan data dengan lengkap. Jumlah unsur pembenaran (warrant) pada jawaban mahasiswa semester 5 dan 7 mendapati nilai tinggi yaitu 71 dan 65.sedangkan mahasiswa semester 1 dan 3 masih tergolong sedikit yaitu hanya 44 dan 43 saja. Mahasiswa semester 7 dan 5 sudah cukup memberikan alasan yang menghubungkan data dengan claim, sedangkan mahasiswa semester 1 dan 3 masih tergolong sedikit dalam hal memberikan alasan. 
Jumlah unsur dukungan (backing) pada jawaban mahasiswa semester 7 memiliki perbedaan yang jauh dengan tingkat mahasiswa lain yaitu 76.sedangkan mahasiswa semester 1, 3, dan 5 berada di angka 50-57. Pada mahasiswa semester 7 sudah cukup dalam hal menyertakan asumsi dalam bidang biologi yang dapat mendukung pembenaran (warrant) secara lengkap dan benar. Namun pada jawaban mahasiswa semester 1, 3, dan 5 masih tergolong rendah dan belum lengkap. Bahkan banyak jawaban yang tidak menyertakan dukungan (backing). Dikatakan bahwa untuk mahasiswa semester 1, 3, dan 5 masih kurang dalam hal penyertaan data, pembenaran, dan dukungan dalam argumennya. Sedangkan untuk unsur klaim antara mahasiswa di setiap jenjang semester sudah cukup bagus dan secara keseluruhan sudah menyertakan klaim.

Sebagian besar mahasiswa hanya mengungkapkan claim dengan sedikit data yang membantu claim tersebut. Hal ini dapat terjadi karena para mahasiswa kurang memiliki landasan teoritis awal, sehingga argumen yang disampaikan kurang kokoh. Para mahasiswa cenderung hanya menyampaikan pendapat pribadi tanpa dukungan. Apabila menyertakan data, data tersebut kurang akurat sesuai dengan pendapat (Probosari, Ramli, dan Indrowati 2016) yang mengatakan bahwa mahasiswa terbiasa mencari sumber pustaka non ilmiah yang tidak terpercaya.

Hal lain yang menyebabkan perbedaan kemampuan argumentasi dari mahasiswa semester 1, 3, 5 dan 7 yaitu pemahaman konsep. Mahasiswa yang lebih memahami materi yang diberikan pada akhirnya akan menunjukkan kemampuan beragumentasi ilmiah yang baik (Probosari dkk. 2016; Muna 2016). Mahasiswa semester 5 dan 7 cenderung lebih memahami materi karena telah menempuh pembelajaran lebih banyak dibandingkan mahasiswa semester 1 dan 3 . Oleh karena itu, kompetensi dalam berargumen perlu dikembangkan melalui memperbanyak literasi dari sumber terpercaya. Kebiasaan berargumen disertai dengan data yang konkret juga pelru dibiasakan di lingkungan mahasiswa sedini mungkin, sehingga mahasiswa mampu menyampaikan argument mereka secara tepat. Berbeda dengan penelitian lainnya yang tidak membandingkan antara argumentasi-argumentasi mahasiswa (Herlanti 2014; Hasnunidah dan Susilo 2014). 
Berdasarkan hasil penelitian yang telah dilakukan, dapat diambil kesimpulan bahwa keterampilan berargumentasi mahasiswa Pendidikan Biologi FKIP UNS berbeda pada setiap jenjang, semakin tinggi jenjang semesternya, mahasiswa akan semakin terampil dalam berrgumentasi. Hasil penilaian tes menunjukan mahasiswa semester 7, 5, 3, 1 secara berturut-turut mendapatkan nilai rata-rata 49,06\%, 37,7\%, 32,11\%, 25,67\%. Namun, kemampuan argumentasi pada setiap jenjang semester masih tergolong kurang baik, hal tersebut disebabkan oleh kualitas argumentasi yang sebagian besar hanya berisi claim dengan adanya data yang kurang akurat yang melandasi claim tersebut, atau bahkan tidak ada.

Adapun saran untuk penelitian selanjutnya, supaya penelitian ini dapat dijadikan acuan/referensi dan penelitian ini dapat dikembangkan lebih luas dan keterbaruan sumber lainnya .

\section{DAFTAR PUSTAKA}

Admoko, Setyo, dan S. Supriyono. 2016. "Workshop Peningkatan Kemampuan Merancang Kegiatan Laboratorium Berorentasi pada Pendekatan Saintifik Bagi Guru Fisika Sidoarjo.” Jurnal Penelitian Fisika dan Aplikasinya (JPFA) 6 (1): 34-42.

Amalia, Nur Fildzah, Ari Widodo, dan Diana Rochintaniawati. 2018. "Kompleksitas Argumentasi Berbasis Isu Sosiosaintifik pada Jenjang SD, SMP, dan SMA.” Assimilation: Indonesian Journal of Biology Education 1 (1): 29-32.

Baan, Anastasia. 2016. "Pengaruh Penggunaan Media Wall Chart dalam Meningkatkan Kemampuan Menulis Karangan Argumentasi Siswa Kelas X. 1 SMA Negeri 1 Sesean.” Perspektif: Jurnal Pengembangan Sumber Daya Insani 1 (1): 30-39.

Ekanara, Bambang, Nuryani Y. Rustaman, dan Hernawati Hernawati. 2016. "Studi Tentang Keterampilan Pembentukan Klaim Mengenai Isu Sosio-Saintifik Siswa Sekolah Menengah Atas Pada Kelompok Budaya Sunda." Biodidaktika, Jurnal Biologi Dan Pembelajarannya 11 (2).

Faiqoh, Nurul, Lia Puji Astuti Nadhirotul Khasanah, Riski Prayitno, Baskoro Adi Prayitno, dan Program. 2018. "Profil Keterampilan Argumentasi Siswa Kelas X dan XI MIPA di SMA Batik 1 Surakarta pada Materi Keanekaragaman Hayati Nurul.” Jurnal Pendidikan Biologi 7 (3): 174-82.

Ginanjar, Wahyu Sukma, dan Setiya Utari. 2015. "Penerapan model argument-driven inquiry dalam pembelajaran IPA untuk meningkatkan kemampuan argumentasi ilmiah siswa SMP.” Jurnal Pengajaran MIPA 20 (1): 32-37. 
Habibah, Sulhatul. 2019. "PARADIGMA POPPERIAN." DAR EL-ILMI: Jurnal Studi Keagamaan, Pendidikan dan Humaniora 6 (2): 303-18.

Handayani, Putri. 2015. "Analisis argumentasi peserta didik kelas x sma muhammadiyah 1 palembang dengan menggunakan model argumentasi toulmin." Jurnal Inovasi dan Pembelajaran Fisika 2 (1): 60-68.

Hasanah, Nur, Tri Sri Noor Asih, dan Iqbal Kharisudin. 2019. "Peningkatan Kemampuan Pemecahan Masalah Matematika Siswa Melalui Model Pembelajaran Fostering Communities of Learners." Dalam PRISMA, Prosiding Seminar Nasional Matematika, 2:622-28.

HASANAH, Umi Nur, Andi Thahir, Komaruddin Komaruddin, dan Rahmahwaty Rahmahwaty. t.t. "MURDER Learning and Self Efficacy Models: Impact on Mathematical Reflective Thingking Ability." Journal for the Education of Gifted Young Scientists 7 (4): 1123-35.

Hasnunidah, Neni, dan Herawati Susilo. 2014. "Profil perspektif sosiokultural mahasiswa dalam berargumentasi pada mata kuliah biologi dasar." Dalam Proceeding Biology Education Conference: Biology, Science, Enviromental, and Learning, 11:729-33.

Herlanti, Yanti. 2014. "Analisis Argumentasi Mahasiswa Pendidikan Biologi Pada Isu Sosiosainfik Konsumsi Genetically Modified Organism (GMO)." Jurnal Pendidikan IPA Indonesia 3 (1).

Ibda, Fatimah. 2015. "Perkembangan Kognitif : Teori Jean Piaget." Intelektualita 3 (1): 27 38.

Karyanti, Karyanti, dan Komarudin Komarudin. 2017. "Pengaruh model pembelajaran kumon terhadap pemahaman matematis ditinjau dari gaya kognitif peserta didik pada mata pelajaran matematika kelas viii smp negeri satu atap 4 pesawaran." Dalam Prosiding Seminar Nasional Matematika dan Pendidikan Matematika, 1:8994.

Kertayasa, I. Nyoman. 2011. "Logika, Riset, dan Kebenaran.” Widyatech Jurnal Sains dan Teknologi 10 (3): 29-44.

Komarudin, Komarudin. 2016. "Falsifikasi Karl Popper Dan Kemungkinan Penerapannya Dalam Keilmuan Islam." At-Taqaddum 6 (2): 444-65.

Kurniawan, Edi Hardi. 2013. "Analisis Hasil Belajar Fisika Siswa Berdasarkan Kemampuan Berpikir Konkret Dan Formal Sman 1 Abung Pekurun Kota Bumi.”

Lestari, Putu Indah, dan Elizabeth Prima. 2018. "Permainan Congklak Dalam Meningkatkan Perkembangan Kognitif Anak Usia 5-6 Tahun.” SINTESA.

LIN, SHU-SHENG, dan JOEL J. MINTZES. 2010. "Learning argumentation skills through instruction in socioscientific issues: the effect of ability level," no. July 2008: 9931017. 
Marliani, Novi. 2015. "Peningkatan Kemampuan Berpikir Kreatif Matematis Siswa Melalui Model Pembelajaran Missouri Mathematics Project (MMP)." Formatif: Jurnal Ilmiah Pendidikan MIPA 5 (1).

Mouraz, Ana, Universidade Aberta, Carlinda Leite, dan Rui Eduardo Trindade. 2014. "Argumentative Skills in Higher Education: A Comparative Approach Argumentative Skills in Higher Education: A Comparative Approach." Journal of Education \& Human Development 3 (1): 1-154.

Muna, Izza Auliyatul. 2016. "Identifikasi Miskonsepsi Mahasiswa PGMI Pada Konsep Hukum Newton Menggunakan Certainty of Response Index (CRI)." Cendekia: Jurnal Kependidikan Dan Kemasyarakatan 13 (2): 309-22.

Nagel, P. Julius F. 2013. "Peluang dan Tantangan Ukm Indonesia Menghadapi Masyarakat Ekonomi Asean 2015." Sustainable Competitive Advantage (SCA) 3 (1).

Probosari, Riezky Maya, Murni Ramli, HARLITA HARLITA, METI INDROWATI, dan SAJIDAN SAJIDAN. 2016. "Profil Keterampilan Argumentasi Ilmiah Mahasiswa Pendidikan Biologi FKIP UNS pada Mata Kuliah Anatomi Tumbuhan." Bioedukasi: Jurnal Pendidikan Biologi 9 (1): 29-33.

Probosari, Riezky Maya, Murni Ramli, dan Meti Indrowati. 2016. "Profil Keterampilan Argumentasi Ilmiah Mahasiswa Pendidikan Biologi FKIP UNS pada Mata Kuliah Anatomi Tumbuhan.” BIOEUKASI 9 (1): 29-33.

Puspitaningrum, Hidayah Zuliana, Supeno Astutik, dan Supeno Supeno. 2018. "Lembar kerja siswa berbasis collaborative creativity untuk melatihkan kemampuan berargumentasi ilmiah siswa SMA." Dalam Quantum: Seminar Nasional Fisika, dan Pendidikan Fisika, 159-64.

Sandhy, Afifah Kurnia, Edy Tandililing, dan Erwina Oktavianty. t.t. "Pengaruh Model Inkuiri Untuk Meningkatkan Keterampilan Argumentasi Peserta Didik Terhadap Materi Getaran Dan Gelombang." Jurnal Pendidikan dan Pembelajaran 7 (10).

Sanisah, Siti. 2010. "Pendidikan tinggi dan pengangguran terbuka: Sebuah dilema." Lentera Pendidikan: Jurnal Ilmu Tarbiyah dan Keguruan 13 (2): 147-59.

Saregar, Antomi. 2016. "Pembelajaran pengantar fisika kuantum dengan memanfaatkan media phet simulation dan LKM melalui pendekatan saintifik: Dampak pada Minat dan Penguasaan Konsep Mahasiswa." Jurnal Ilmiah Pendidikan Fisika Al-Biruni 5 (1): 53-60.

Setiawati, Ina, dan Ilah Nurlaelah. 2017. "Analisis Profil Kemampuan Berargumentasi Guru dan Mahasiswa Calon Guru dalam Pembelajaran Biologi Menggunakan Model Toulmin's Argumen Pattern (TAP) dan Upaya Perbaikannya." Quagga: Jurnal Pendidikan dan Biologi 9 (01). 
Setyawan, Imam. 2011. "Peran Ketrampilan Belajar Kontekstual Dan Kemampuan Empati Terhadap Adversity Intelligence Pada Mahasiswa.” Jurnal Psikologi 9 (1).

Suraya. 2018. Keterampilan Argumentasi Ilmiah Dan Berpikir Kritis Melalui Metode Debat Pada Materi Keanekaragaman Hayati Siswa Kelas X di MAN 1 Natuna Kepulauan Riau. Pontianak. UMP.

Syafitri, Rita, Rayandra Asyhar, dan Asrial Asrial. 2016. "Pengaruh Model Inquiry Training dan Berpikir Kritis Terhadap Kemampuan Berpikir Ilmiah Mahasiswa pada Mata Kuliah Kimia Dasar." Edu-Sains: Jurnal Pendidikan Matematika dan Ilmu Pengetahuan Alam Universitas Jember 5 (1).

Tahaha, Hisban, dan Edhy Rustan. 2017. "Orientasi Religiusitas dan Efikasi Diri dalam Hubungannya dengan Kebermaknaan Pendidikan Agama Islam pada Mahasiswa IAIN Palopo.” Jurnal Studi Agama Dan Masyarakat 13 (2): 163-79.

Yusri, Radhya. 2016. "Pengaruh Pendekatan Problem Centered Learning terhadap Kemampuan Pemahaman Konsep Matematis Siswa Kelas X SMA Negeri Kabupaten Solok." PROSIDING 2 (1): 165-71.

Zahratul Hikmah, Naila, dan Nadi Suprapto. 2019. "Penerapan Model Pembelajaran Diskusi Kelas Tipe Buzz Group untuk Meningkatkan Kemampuan Argumentasi Ilmiah Peserta Didik Kelas X MIA Materi Usaha dan Energi." Inovasi Pendidikan Fisika 8 (2). 